\title{
Profil Kemandirian Belajar Siswa Dan Implikasinya Bagi Program Bimbingan Belajar
}

\author{
Irma Haerani \\ Universitas Sultan Ageng Tirtayasa, Serang, Indonesia \\ irmahae01@gmail.com \\ Deasy Yunika Khairun \\ Universitas Sultan Ageng Tirtayasa, Serang, Indonesia \\ deasyyunikakhairun@untirta.ac.id \\ Putri Dian Dia Conia \\ Universitas Sultan Ageng Tirtayasa, Serang, Indonesia \\ putriconia@untirta.ac.id
}

\begin{abstract}
Abstrak
Penelitian ini bertujuan untuk mengetahui gambaran mengenai kemandirian belajar siswa kelas IX tahun ajaran 2019/2020 di SMPN 3 Kota Serang. Metode penelitian yang digunakan dalam penelitian ini adalah metode deskriptif dengan pendekatan kuantitatif. Subjek penelitian yaitu sebanyak 159 siswa/i kelas IX tahun ajaran 2019/2020 yang dipilih secara acak. Instrument yang digunakan yaitu kuesioner kemandirian belajar siswa. Hasil penelitian menunjukan tingkat kemandirian belajar siswa kelas IX tahun ajaran 2019/2020 di SMPN 3 Kota Serang yaitu pada kategori rendah dengan persentase $17.61 \%$ sebanyak 28 siswa, kategori sedang dengan persentase 64.78\% sebanyak 103 siswa, kategori tinggi dengan persentase $17.61 \%$ sebanyak 28 siswa. Setelah mengetahui gambaran kemandirian belajar siswa, maka disusun sebuah rancangan program bimbingan belajar berdasarkan hasil penelitian yang diperoleh. Program bimbingan belajar diharapkan dapat membantu siswa untuk mengatasi kesulitan belajar yang dihadapi, dan mengembangkan cara belajar yang efektif, sehingga kemandirian belajar siswa dapat di tingkatkan.
\end{abstract}

Kata kunci : Kemandirian Belajar, Program Bimbingan Belajar 


\begin{abstract}
Profile of Independence Learning Students And Their Implications For The Program of Learning Guidance. This study aims to find a picture of the learning independence of class IX students in the 2019/2020 school year at SMPN 3 Serang City. The research method used in this study is a descriptive method with a quantitative approach. The research subjects were 159 students of class IX in the 2019/2020 school year that were randomly selected. The instrument used was a student learning independence questionnaire. The results showed the level of learning independence of class IX students in the 2019/2020 school year at SMPN 3 Serang City in the low category with a percentage of $17.61 \%$ by 28 students, the medium category with a percentage of $64.78 \%$ by 103 students, a high category with a percentage of $17.61 \%$ by 28 students . After knowing the picture of students' learning independence, a study guidance program is arranged based on the results of the research obtained. The tutoring program is expected to be able to help students to overcome the learning difficulties they face, and to develop effective ways of learning, so that students' learning independence can be improved.
\end{abstract}

Keywords: Learning Independence, Program of Learning Guidance

\title{
A. Pendahuluan
}

Kemandirian belajar merupakan salah satu hal penting yang menunjang keberhasilan siswa dalam belajar. Sikap mandiri perlu ditanamkan sejak dini pada diri individu sebagai bentuk dari pengembangan potensi diri. Sesuai dengan yang tertuang dalam Bab II Undang-Undang Nomor 20 Tahun 2003 tentang Sistem Pendidikan Nasional (Kurniawati, 2010: 35) menyatakan bahwa pendidikan nasional, berfungsi mengembangkan kemampuan dan membentuk watak serta peradaban bangsa yang bermartabat, dalam rangka mencerdaskan kehidupan bangsa, bertujuan untuk berkembangnya potensi peserta didik agar menjadi manusia yang beriman dan bertaqwa kepada Tuhan Yang Maha Esa, berakhlak mulia, sehat, berilmu, cakap, kreatif, mandiri, dan menjadi warga negara yang demokratis, serta bertanggung jawab.

Peserta didik pada pendidikan menengah berada pada rentang usia 12-14 yang termasuk kategori remaja. Piaget (Mohammad \& Asrori, 2011: 67) 
mengemukakan bahwa remaja berada dalam tahap perkembangan kognitif operasional formal. Gunarsa (Herlina, 2013:2) mengemukakan bahwa pada tahap ini remaja sudah mampu berpikir secara sistematik, dengan melakukan bermacam-macam penggabungan, memahami adanya bermacam-macam aspek pada suatu persoalan yang dapat diselesaikan seketika. Anak dimasa operasional formal, jika dihadapkan pada suatu masalah, ia akan memulai dengan menganalisis faktor apa saya yang mungkin mempengaruhi dan memprediksi tentang akibat apa yang mungkin akan terjadi. Maka pada tahap ini, anak sudah mampu untuk berpikir dalam memecahkan masalah dan terlibat aktif dalam proses pembelajaran.

Ahmadi dan Uhbiyati (2012: 13) menjelaskan bahwa kemandirian belajar adalah belajar mandiri, tidak menggantungkan diri kepada orang lain, siswa dituntut untuk memiliki keaktifan dan inisiatif sendiri dalam belajar, bersikap, berbangsa maupun bernegara. . Selain itu, Knowles (Santosa, 2014: 2) berpendapat kemandirain belajar merupakan suatu proses belajar dimana setiap siswa atau individu dapat mengambil inisiatif, dengan atau tanpa bantuan orang lain, dalam hal mendiagnosa kebutuhan belajar, merumuskan tujuan belajar, mengidentifikasi sumber-sumber belajar (baik berupa orang maupun bahan), memilih dan menerapkan strategi belajar yang sesuai bagi dirinya, serta mengevaluasi hasil belajarnya.

Hidayati (2013) mengemukakan bahwa kemandirian dalam belajar dapat terlihat dari tingkah laku dan cara belajar yang dilakukan oleh siswa. Siswa yang tekun dalam mengerjakan tugas, terlibat aktif dalam proses kegiatan belajar mengambarkan kemandirian belajar pada anak yang baik. Hidayati juga berpendapat bahwa siswa yang memiliki kemandirian belajar yang baik, akan mampu menyelesaikan tugasnya dengan baik tanpa mencontek tugas temannya.

Penelitian yang dilakukan oleh Thoken, Asrori, dan Purwanti (2017) mengenai kemandirian belajar pada siswa kelas X SMA Kemala Bhayangkari 
Sungai Raya, menunjukan bahwa terdapat siswa yang belum memiliki kemandirian belajar yang baik. Hal itu tampak dari perilaku yang dilakukan oleh siswa, yaitu sering mencontek saat ulangan, tidak mengerjakan tugas yang diberikan guru, bercanda saat guru belum masuk kelas, mengobrol dengan teman saat guru menjelaskan, dan kurangnya inisiatif untuk bertanya jika ada materi yang belum dipahami. Hasil penelitian tersebut selaras dengan hasil observasi yang dilakukan oleh peneliti selama masa PPLK (Program Pengalaman Lapangan Kependidikan yaitu siswa kelas IX Kurang bertanggung jawab atas tugas yang diberikan oleh guru seperti tidak mengerjakan tugas yang diberikan atau mencontek jawaban temannya.

Hal tersebut diperkuat dengan hasil Angket Kebutuhan Peserta Didik (AKPD) di kelas IX SMPN 3 Kota Serang tahun ajaran 2019/2020. Hasil Angket Kebutuhan Peserta Didik (AKPD) menunjukan bahwa terdapat butir pernyataan yang menunjukan kebutuhan siswa dalam bidang belajar tinggi yaitu pada butir, kadang saya masih suka mencontek saat tes dengan presentase $2.85 \%$, saya belum paham cara meningkatkan motivasi belajar dengan presentase $2.16 \%$, saya belum bisa mengevaluasi hasil prestasi belajar dengan presentase $2.73 \%$, saya belum bisa belajar secara rutin dengan presentase 2.96\%, saya belum paham cara meningkatkan konsentrasi belajar dengan presentase 2.16\%. Butir-butir pernyataan tersebut menunjukan bahwa kemandirian belajar siswa kelas IX masih rendah.

Kemandirian belajar merupakan salah satu bagian terpenting dalam proses belajar siswa. Siswa yang memiliki kemandirian belajar, akan mampu untuk menentukan tujuan belajar yang ingin dicapainya. Siswa dengan kemandirian belajar yang baik, cenderung akan memiliki proses belajar yang baik pula. Namun, tidak semua siswa memiliki kemampuan tersebut. Maka dari itu, siswa membutuhkan bantuan dari tenaga pendidik. Haefany (2015: 31) menjelaskan bahwa tujuan utama para pendidik ialah membantu masing-masing individu untuk 
mengenal diri mereka sendiri sebagai manusia yang unik, dan membantunya dalam mewujudkan potensi-potensi yang ada pada diri mereka.

Guru bimbingan dan konseling memiliki peran untuk membantu siswa dalam mengatasi kesulitan yang dialami dan mengembangkan potensi dirinya, karena bimbingan konseling adalah suatu proses pemberian bantuan secara terusmenerus dalam perkembangan individual untuk mencapai kemampuan, pemahaman dan pengarahan diri, penyesuaian diri serta pemecahan masalah yang dihadapi, sehingga dapat bertindak wajar sesuai dengan tuntutan lingkungannya (Bastomi, 2017).

Melihat kebutuhan peserta didik dalam bidang belajar yang tinggi maka perlunya pelayanan bimbingan dan konseling di sekolah guna membantu siswa dalam mengatasi hambatan yang dialaminya dalam belajar. Guru bimbingan dan konseling dapat memberikan layanan bimbingan belajar sebagai upaya memfasilitasi siswa untuk mencapai tugas-tugas perkembangan yang optimal dan memandirikan. Thantawi (Unsuri, 2009) menyatakan bimbingan belajar adalah bidang pelayanan bimbingan dan konseling yang membantu individu atau peserta didik dalam mengembangkan diri, sikap, dan kebiasaan belajar yang baik untuk menguasai pengetahuan dan keterampilan serta menyiapkan untuk pendidikan pada tingkat yang lebih tinggi.

\section{B. Pembahasan}

\section{Kemandirian belajar}

\section{a. Definisi Kemandirian Belajar}

Parker (Saidah, 2014: 12-13) berpendapat bahwa, kemandirian adalah kemampuan untuk mengelola semua yang dimilikinya sendiri yaitu mengetahui bagaimana mengelola waktu, berjalan dan berpikir secara mandiri, disertai dengan kemampuan dalam mengambil resiko dan memecahkan masalah. Pendapat lain menurut Steinberg (Munadiroh, 2015) yang menjelaskan bahwa kemandirian merupakan kemampuan dalam mengatur perilaku sendiri untuk 
memilih dan memutuskan keputusan sendiri, serta mampu mempertanggung jawabkan tingkah lakunya sendiri tanpa terlalu tergantung pada orangtua.

Begitupun dalam hal belajar, individu harus bisa mengatur dirinya kegiatan belajarnya. Syah (Bunandar, 2016) menyatakan, belajar adalah tahapan perubahan seluruh tingkah laku individu yang relatif menetap sebagai hasil pengalaman dan interaktif dengan lingkungan yang melibatkan proses kognitif. Individu yang melakukan proses belajar dengan baik, akan terlibat aktif baik secara fisik maupun pikirannya, sehingga mendapat pemahaman yang dapat mengubah tingkah lakunya.

Nurhayati (Indaryanti, 2019: 2) berpendapat bahwa kemandirian belajar adalah suatu proses pembelajaran yang dilakukan secara terbuka dan dapat dipertanggungjawabkan untuk mengatur dirinya sendiri dalam menentukan aspek kebutuhan, kemauan, tidak bergantung pada orang lain dan mampu bertanggung jawab terhadap pilihannya. Song dan Hill (2007: 38) menyatakan bahwa kemandirian belajar berkaitan dengan proses dan atribut pribadi. Proses meliputi perencanaan, pemantauan, dan mengevaluasi. Sedangkan atribut pribadi meliputi penggunaan sumber daya, penggunaan strategi dan motivasi. Selain itu, yang menjadi kunci tercapainya tujuan pendidikan untuk memfasilitasi pembelajaran siswa terletak pada desain lingkungan belajar.

Berdasarkan pendapat-pendapat di atas dapat disimpulkan bahwa kemandirian belajar siswa merupakan suatu usaha siswa untuk belajar atas inisiatifnya sendiri, belajar menentukan tujuan belajar, membuat perencanaan belajar, memilih sumber-sumber belajar, mengevaluasi proses dan hasil belajar, serta menentukan kegiatan belajar sesuai dengan kebutuhannya sendiri agar mencapai keberhasilan belajar.

\section{b. Aspek Kemandirian Belajar}

Song and Hill (2007: 31-32) menyebutkan bahwa kemandirian terdiri dari beberapa aspek, yaitu :

1) Personal Attributes 
Personal attributes merupakan aspek yang berkenaan dengan motivasi dari siswa, penggunaan sumber belajar, dan strategi belajar. Motivasi belajar merupakan keinginan yang terdapat dalam diri seseorang yang merangsang pembelajar untuk melakukan kegiatan belajar. Sumber belajar yang digunakan siswa tidak terbatas, selama sesuai dengan materi yang dipelajari dan dapat menambah pengetahuan siswa. Menjadi hal yang penting untuk memperhatikan sumber dan tanggal informasi sehingga dapat memberikan penilaian yang baik, apakah informasi yang diperoleh dapat dipercaya kebenaran atau keakuratannya. Sedangkan, yang dimaksud dengan strategi belajar adalah segala usaha yang dilakukan siswa, untuk menguasai materi yang sedang dipelajari, termasuk usaha yang dilakukan apabila siswa tersebut mengalami kesulitan.

2) Processes

Processes merupakan aspek yang berkenaan dengan otonomi proses pembelajaran yang dilakukan oleh siswa meliputi perencanaan, monitoring, serta evaluasi pembelajaran. Kegiatan perencanaan meliputi: a) mengelola waktu secara efektif (pembuatan jadwal belajar, menyusun kalender studi untuk menulis atau menandai tanggal-tanggal penting dalam studi, tanggal penyerahan tugas makalah, tugas PR, dan tanggal penting lainnya, mempersiapkan buku, alat tulis, dan peralatan belajar lain), b) menentukan prioritas dan menata diri (mencari tahu mana yang paling penting dilakukan terlebih dahulu dan kapan harus dilakukan). Kegiatan monitoring meliputi : a) aktif selama proses pembelajaran, b) membuat cacatan apabila diperlukan, c) tetap melaksanakan kegiatan pembelajaran meskipun guru tidak hadir. Sedangkan yang termasuk kegiatan evaluasi pembelajaran antara lain, a) memperhatikan umpan balik dari tugas yang telah dilaksanakan sehingga dapat diketahui letak kesalahannya, b) mengerjakan kembali soal/ tes di rumah, dan c) berusaha memperbaiki kesalahan yang telah dilakukan.

3) Learning Context 
Fokus dari learning context adalah faktor lingkungan dan bagaimana faktor tersebut mempengaruhi tingkat kemandirian siswa. Ada beberapa faktor dalam konteks pembelajaran yang dapat mempengaruhi pengalaman mandiri pembelajar antara lain, sumber daya dan structure \& nature of task. Sumber daya berkaitan dengan konteks pembelajaran yang dirancang oleh guru, seperti cara guru membangun interaksi dengan siswa dikelas. Sedangkan structure dan nature of task berkaitan dengan kapan, dimana, dan bagaimana mereka belajar atas tugas yang telah diberikan oleh guru.

Kemandirian merupakan sikap yang perlu ditanamkan sejak dini pada setiap individu. Sikap mandiri tidak muncul dengan sendirinya, melainkan dapat dilakukan melalui proses pembiasaan diri. Pembiasaan diri dapat dimulai dari membuat perencanaaan belajar, belajar secara rutin, dan mengerjakan tugas tepat waktu.

\section{Program Bimbingan Belajar untuk Meningkatkan Kemandirian Belajar} Siswa

Yusuf dan Nurihsan (2010: 10-11) menjelaskan bahwa bimbingan belajar adalah bimbingan yang diarahkan untuk membantu para individu dalam menghadapi dan memecahkan masalah-masalah akademik dengan cara mengembangkan suasana-suasana belajar-mengajar yang kondusif agar terhindar dari kesulitan belajar. Syahputra (Syahputra, 2017) mengemukakan bahwa para pembimbing membantu individu mengatasi kesulitan belajar, mengembangkan cara belajar yang efektif, membantu individu agar sukses dalam belajar, dan agar mampu menyesuaikan diri terhadap semua tuntutan program atau pendidikan.

Surur (Surur, 2004: 38) menjelaskan bahwa tujuan penyusunan program bimbingan dan konseling yaitu agar guru bimbingan konseling memiliki pedoman yang pasti dan jelas agar kegiatan layanan bimbingan dan konseling di sekolah dapat terlaksana dengan lancar, efektif, dan efisien, serta hasilhasilnya dapat ditindak lanjuti. Program yang telah dirancang oleh guru 
bimbingan dan konseling dapat dijadikan sebagai pedoman dalam melaksanakan layanan kepada siswa. Program bimbingan belajar adalah pedoman layanan yang akan diberikan oleh guru bimbingan dan konseling guna membantu siswa mengatasi kesulitan belajar yang dihadapi dan mengembangkan kebiasaan belajar yang baik.

Yusuf dan Nurihsan (2010: 6) mengatakan bahwa, tujuan dari bimbingan belajar diantaranya :

a. Agar siswa memiliki sikap dan kebiasaan belajar yang positif, seperti kebiasaan membaca buku, disiplin dalam belajar, mempunyai perhatian terhadap semua pelajaran, dan aktif mengikuti semua kegiatan belajar yang diprogramkan.

b. Memiliki motif yang tinggi untuk belajar sepanjang hayat.

c. Memiliki keterampilan atau teknik belajar yang efektif, seperti keterampilan membaca buku, menggunakan kamus, mencatat pelajaran, dan mempersiapkan diri menghadapi ujian.

d. Memiliki keterampilan menetapkan tujuan dan perencanaan pendidikan, seperti membuat jadwal belajar, mengerjakan tugas-tugas, memantapkan diri dalam pelajaran tertentu, dan berusaha memperoleh informasi tentang berbagai hal dalam rangka mengembangkan wawasan yang lebih luas.

e. Memiliki kesiapan mental dan kemampuan untuk menghadapi ujian.

Sriyono (Sriyono, 2016) memaparkan program bimbingan belajar mengandung prinsip-prinsip sebagai berikut :

1) Bimbingan belajar dibutuhkan oleh semua anak di sekolah.

2) Bimbingan belajar mempunyai fokus pada kegiatan belajar siswa.

3) Di dalam program bimbingan belajar, konselor, guru, kepala panti asuhan merupakan tim yang bekerja sama Konselor, guru dan kepala panti asuhan bekerja sama dalam membantu menyelesaikan masalah belajar yang dihadapi siswa. 
4) Kurikulum yang terorganisir dan terencana merupakan bagian yang utama dari bimbingan belajar.

5) Bimbingan belajar memberikan pelayanan belajar bagi setiap anak atau siswa.

6) Bimbingan belajar berfokus pada kebutuhan - kebutuhan anak dalam belajar.

\section{Metode Penelitian}

Metode yang digunakan dalam penelitian ini adalah metode deskriptif dengan pendekatan kuantitatif. Bertujuan untuk mendapatkan gambaran lengkap mengenai kemandirian belajar siswa. Lokasi penelitian yaitu SMPN 3 Kota Serang yang terletak di Jl. Ki Sahal No.3, Lopang, Kec. Serang, Kota Serang, Provinsi Banten. Subjek penelitian adalah siswa/i kelas IX dengan keseluruhan populasi sebanyak 263, kemudian ditentukan jumlah sampel dari populasi untuk batas kesalahan toleransi $0.05 \%$, sehingga menghasilkan jumlah sampel 159 orang. Teknik pengumpulan sampel pada penelitian ini yaitu menggunakan Simple random sampling. Alat pengumpulan data menggunakan kuesioner dengan skala ukur kemandirian belajar sebanyak 50 item dengan nilai reliabilitas 0.85 . data yang diperoleh dianalisis menggunakan teknik analisis kuantitatif deskriptif.

\section{Hasil Penelitian dan Pembahasan}

\section{a. Hasil Penelitian}

Data mengenai kemandirian belajar siswa kelas IX tahun ajaran 2019/2020 di SMPN 3 Kota Serang diperoleh dari kuesioner atau angket dan disebar kepada sampel penelitian yang berjumlah 159 responden menunjukan hasil sebagai berikut :

Tabel 1. Tingkat Kemandirian Belajar Siswa

\begin{tabular}{|l|l|l|c|c|}
\hline Variabel & Kategori & Rentang Skor Nilai & Frekuensi & Persentase \\
\hline \multirow{2}{*}{$\begin{array}{l}\text { Kemandirian } \\
\text { Belajar }\end{array}$} & Rendah & $\mathrm{X}<73,39$ & 28 & $17.61 \%$ \\
\cline { 2 - 5 } & Sedang & $73,39 \leq \mathrm{X}<96,81$ & 103 & $64.78 \%$ \\
\cline { 2 - 5 } & &
\end{tabular}




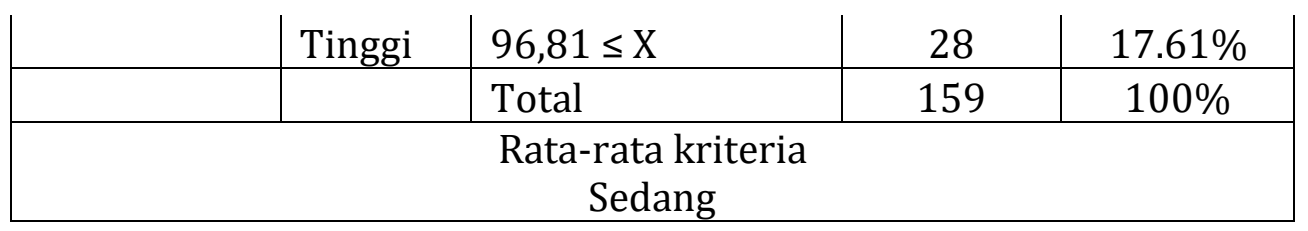

Berdasarkan tabel 1 diatas, dapat disimpulkan bahwa sebagian besar siswa kelas IX di SMPN 3 Kota Serang Tahun Ajaran 2019/2020 memiliki kemandirian belajar dalam kategori sedang, karena hasil persentase menunjukan bahwa 64.78\% yang terdiri dari 103 siswa berada pada kategori sedang, 28 siswa berada pada kategori tinggi dengan persentase 17.61\%, dan 28 siswa lainnya berada pada kategori rendah dengan persentase $17.61 \%$.

Selanjutnya, gambaran kemandirian belajar siswa berdasarkan indikator dapat dilihat pada grafik berikut :

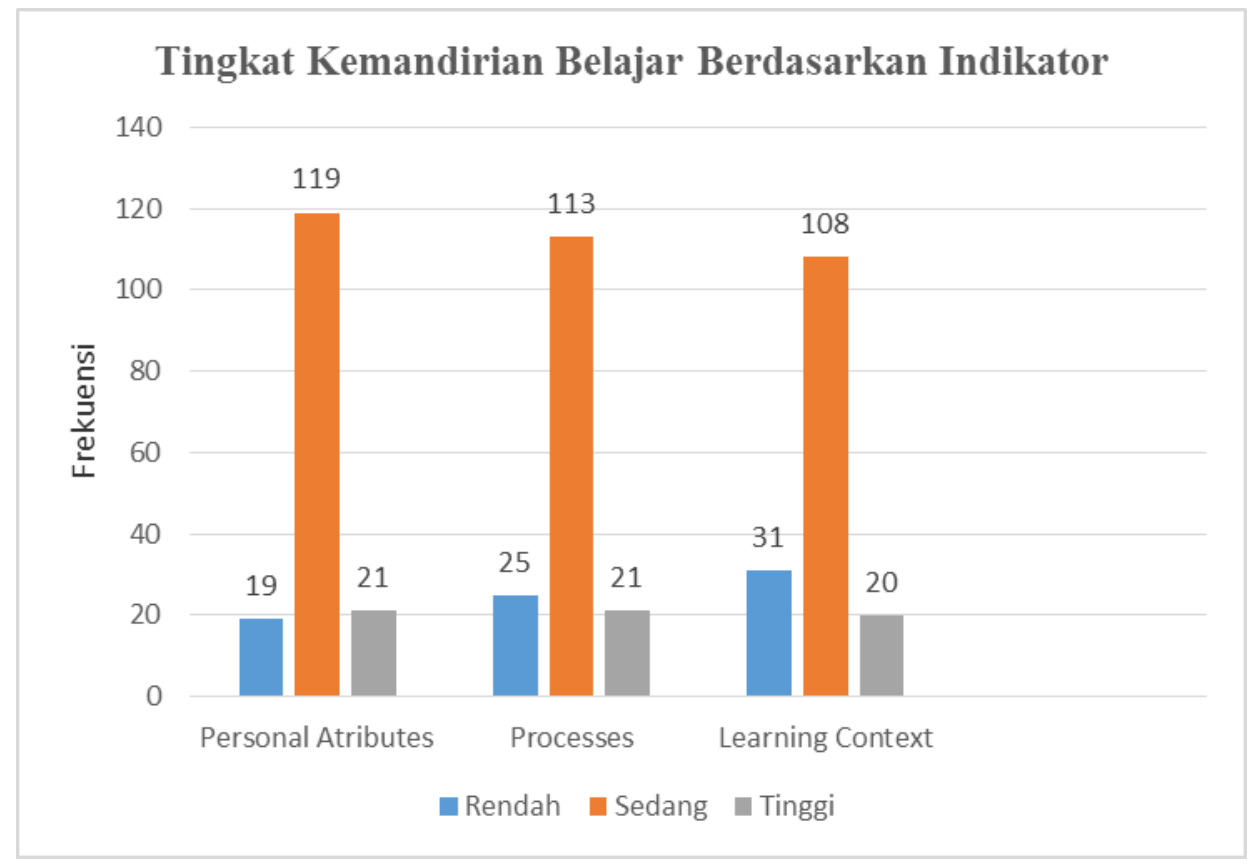

\section{Personal Attributes}

Tabel 2. Tingkat Kemandirian Belajar Siswa Pada Indikator Personal Attributes 


\begin{tabular}{|l|l|l|c|c|}
\hline Indikator & Kategori & Rentang Skor Nilai & Frekuensi & Persentase \\
\hline \multirow{2}{*}{$\begin{array}{l}\text { Personal } \\
\text { Atributes }\end{array}$} & Rendah & $\mathrm{X}<38.96$ & 19 & $11.95 \%$ \\
\cline { 2 - 5 } & Sedang & $38.96 \leq \mathrm{X}<51.05$ & 119 & $74.85 \%$ \\
\cline { 2 - 5 } & Tinggi & $51.05 \leq \mathrm{X}$ & 21 & $13.20 \%$ \\
\hline \multicolumn{2}{|r|}{ Total } & 159 & $100 \%$ \\
\hline
\end{tabular}

Berdasarkan hasil perhitungan diperoleh bahwa sebagian besar siswa berada kategori sedang yaitu 119 siswa dengan persentase sebesar 74.85\%. Sedangkan, siswa yang lainnya pada kategori tinggi terdapat 21 siswa dengan persentase $13.20 \%$ dan pada kategori rendah terdapat 19 siswa dengan persentase 11.95\%. Artinya, bahwa siswa kelas IX di SMPN 3 Kota Serang Tahun Ajaran 2019/2020 dapat dikatakan sudah cukup mampu memiliki aspek kemandirian belajar pada indikator personal attributes.

2. Processes

Tabel 2. Tingkat Kemandirian Belajar Siswa Pada Indikator Processes

\begin{tabular}{|l|l|l|c|c|}
\hline Indikator & Kategori & Rentang Skor Nilai & Frekuensi & Persentase \\
\hline \multirow{3}{*}{ Processes } & Rendah & $\mathrm{X}<21.69$ & 25 & $15.73 \%$ \\
\cline { 2 - 5 } & Sedang & $21.69 \leq \mathrm{X}<31.13$ & 113 & $71.07 \%$ \\
\cline { 2 - 5 } & Tinggi & $31.13 \leq \mathrm{X}$ & 21 & $13.20 \%$ \\
\hline \multicolumn{2}{|r|}{ Total } & 159 & $100 \%$ \\
\hline
\end{tabular}

Berdasarkan hasil perhitungan diperoleh bahwa sebagian besar siswa berada kategori sedang yaitu 113 siswa dengan persentase sebesar 71.07\%. Sedangkan, siswa yang lainnya pada kategori tinggi terdapat 21 siswa dengan persentase $13.20 \%$ dan pada kategori rendah terdapat 25 siswa dengan persentase 15.73\%. Artinya, bahwa siswa kelas IX di SMPN 3 Kota Serang Tahun Ajaran 2019/2020 dapat dikatakan sudah cukup mampu memiliki aspek kemandirian belajar pada indikator processes.

\section{Learning Context}

\section{Tabel 2. Tingkat Kemandirian Belajar Siswa Pada Indikator Learning Context}




\begin{tabular}{|l|l|l|c|c|}
\hline Indikator & Kategori & Rentang Skor Nilai & Frekuensi & Persentase \\
\hline \multirow{2}{*}{$\begin{array}{l}\text { Learning } \\
\text { Context }\end{array}$} & Rendah & $\mathrm{X}<11.19$ & 31 & $19.50 \%$ \\
\cline { 2 - 5 } & Sedang & $11.19 \leq \mathrm{X}<16.15$ & 108 & $67.92 \%$ \\
\cline { 2 - 5 } & Tinggi & $16.15 \leq \mathrm{X}$ & 20 & $12.58 \%$ \\
\hline \multicolumn{2}{|r|}{ Total } & 159 & $100 \%$ \\
\hline
\end{tabular}

Berdasarkan hasil perhitungan diperoleh bahwa sebagian besar siswa berada kategori sedang yaitu 108 siswa dengan persentase sebesar 67.92\%. Sedangkan, siswa yang lainnya pada kategori tinggi terdapat 20 siswa dengan persentase $12.58 \%$ dan pada kategori rendah terdapat 31 siswa dengan persentase 19.50\%. Artinya, bahwa siswa kelas IX di SMPN 3 Kota Serang Tahun Ajaran 2019/2020 dapat dikatakan sudah cukup mampu memiliki aspek kemandirian belajar pada indikator learning context.

\section{b. Pembahasan}

\section{Gambaran Kemandirian Belajar Siswa Kelas IX di SMPN 3 Kota Serang}

Berdasarkan hasil data angket penelitian tentang kemandirian belajar siswa, diperoleh hasil bahwa kemandirian belajar siswa kelas IX di SMPN 3 Kota Serang tergolong pada tiga kategori yaitu tinggi, sedang, dan rendah. Responden terbanyak yaitu 103 siswa dengan persentase sebesar 64.78\% pada kategori sedang. Artinya masih terdapat siswa yang belum memiliki kemandirian belajar yang baik sehingga perlu ditingkatkan.

Siswa yang berada pada kategori kemandirian belajar yang tinggi sudah mampu memiliki motivasi belajar yang tinggi, mampu menggunakan sumber belajar dengan baik, menerapkan strategi belajar yang tepat, membuat perencanaan belajar, melakukan monitoring dalam belajar, mengevaluasi hasil belajar, dan dapat mengatur kegiatan belajarnya. Sedangkan, siswa yang berada pada kategori kemandirian belajar yang sedang dan rendah, belum sepenuhnya memiliki karakteristik diatas. Siswa yang kemandirian belajarnya dalam kategori sedang dapat dikatakan sudah memiliki kemandirian belajar, namun belum sepenuhnya dapat melaksanakan aktivitas yang menunjukan kemandirian 
belajar secara rutin. Siswa yang berada pada kategori rendah dalam kemandirian belajarnya merupakan siswa yang belum mampu menunjukan karakteristik kemandirian belajar dalam menerapkan kegiatan belajarnya.

Isnawati dan Samian (Isnawati \& Samian, 2015) mengatakan bahwa yang menjadi alasan mengapa anak kurang mandiri dalam belajar, salah satunya yaitu kurangnya motivasi dalam belajar. Tumbuhnya motivasi dalam belajar yang kuat pasti akan menumbuhkan kemandirian dalam belajarnya. Thoken, dkk., (2017) menyatakan bahwa pengaruh kemandirian belajar penting untuk mengukur hasil pencapaian belajar yang maksimal, sebab dengan siswa memiliki kemandirian belajar yang baik, ia akan memiliki wawasan belajar yang luas dan inisiatif untuk melakukan proses belajar yang baik di sekolah maupun di rumah dengan memanfaatkan fasilitas dan sumber belajar yang tersedia.

Kemandirian belajar menjadi salah satu hal yang penting karena dengan memiliki kemandirian siswa akan mampu untuk menentukan dan mengatur segala aktivitas belajanya dengan teratur, serta mampu memecahkan hambatan atau kesulitan belajar yang dihadapinya. Remaja yang telah memiliki kemandirian mampu untuk menentukan sendiri keputusan yang akan diambilnya sehingga ia tidak menggantungkan dirinya pada orang lain. Yanti dan Surya (2017: 5) berpendapat bahwa dengan ditumbuh kembangkannya kemandirian pada siswa, maka akan membuat siswa dapat mengerjakan segala sesuatu sesuai dengan kemampuan yang dimilikinya secara optimal sehingga tidak menggantungkan dirinya pada orang lain.

\section{Gambaran Kemandirian Belajar Siswa Berdasarkan Indikator}

Gambaran kemandirian belajar siswa pada indikator Personal Atributes berada pada kategori sedang. Artinya siswa sudah cukup mampu memiliki aspek kemandirian belajar pada indikator personal attributes. Namun, masih terdapat siswa yang belum sepenuhnya memiliki motivasi belajar tinggi, mampu mengatur dirinya sendiri untuk mencari dan mempelajari sumber belajar yang 
sesuai dengan kebutuhannya, serta menentukan strategi belajar yang cocok untuk menyelesaikan tugasnya.

Song dan Hill (2007: 31) menjelaskan bahwa personal attributes adalah aspek yang berkenaan dengan motivasi siswa, penggunaan sumber belajar, dan strategi belajar yang digunakan oleh siswa. Nurhayati (Darmawanti, 2017) bahwa untuk mencapai kemandirian belajar siswa harus dibekali oleh motivasi, agar siswa mampu memulai kegiatan belajar, memelihara kondisi belajar, melakukan proses belajar, dan mengevaluasi hasil belajar dengan baik. Selain itu, pemilihan sumber belajar pun menjadi hal yang perlu diperhatikan.

Mulyasa (Rimawati, 2016) menjelaskan bahwa yang harus diperhatikan dalam pemilihan sumber belajar adalah kesesuaian sumber belajar dengan standar kompetensi yang akan diwujudkan dalam pembelajaran. Siswa harus mengetahui kompetensi yang perlu dikuasainya. Sumber belajar siswa dapat berupa informasi yang disampaikan oleh guru, informasi yang terdapat dalam buku-buku pelajaran, maupun informasi yang diperoleh melalui media internet. Penentuan strategi belajar pun menjadi salah satu hal yang penting agar siswa dapat menyelesaikan masalah belajar yang dihadapinya. Yanti dan Surya (2017: 5)mengemukakan bahwa siswa akan mendiskusikan atau bertanya kepada teman, guru atau pihak lain yang sekiranya lebih berkompeten dalam mengatasi kesulitan tersebut ketika siswa sedang mengalami kesulitan.

Kemudian, gambaran kemandirian belajar siswa pada indikator Processes berada pada kategori sedang. Siswa belum sepenuhnya mampu menerapkan secara teratur perencanaan belajar, monitoring proses belajar, dan mengevalasi belajarnya sehingga perlu ditingkatkan kembali. Sunarto (Suardana, 2012) menyatakan apabila siswa memperoleh peluang untuk mengembangkan kemandirian belajarnya secara maksimal, maka siswa akan mampu memiliki kebiasaan belajar yang baik, sehingga hasil yang diperoleh akan lebih optimal. Jika siswa jarang memonitoring dan mengevaluasi belajarnya, ia akan kurang 
mengetahui hal-hal apa saja yang perlu diperbaikinya atau ditingkatkannya, dan hambatan apa saja yang diperolehnya selama proses belajar.

Islam (Yanti \& Surya, 2017: 14) mengatakan bahwa kemandirian belajar sebagai bentuk belajar yang memiliki tanggung jawab untuk merencanakan, melaksanakan, dan mengevaluasi usahanya. Selaras dengan yang dikatakan oleh Yang (Sugandi, 2013) bahwa peserta didik yang kemandirian belajarnya tinggi cenderung lebih baik dalam pengawasannya sendiri, yaitu mampu memantau, mengevaluasi, dan mengatur belajarnya secara efektif. Tanpa mengevaluasi hasil belajarnya, siswa tidak akan mengetahui hal-hal apa saja yang perlu diperbaiki atau ditingkatkan kembali dalam belajarnya.

Selanjutnya, gambaran kemandirian belajar siswa pada indikator Learning Context berada pada kategori sedang. Siswa belum sepenuhnya mampu menerapkan keaktifan selama proses belajar dikelas dan jarang merespon saat guru bertanya atau meminta pendapat siswa. Siswa perlu membangun keaktifan dirinya sendiri selama proses kegiatan belajar mengajar berlangung, agar proses belajar dapat dilakukan dengan baik.

Mustika (Mustika, 2015) menjelaskan bahwa tujuan dan fungsi guru adalah menggerakan siswanya dengan mempengaruhi, membimbing, dan mengarahkan agar siswa berbuat atau berperilaku sesuai dengan tujuan yang ingin dicapai dalam kegiatan proses belajar mengajar. Namun, jika siswa tidak berusaha untuk mendukung pembelajaran yang diterapkan oleh guru, maka tujuan pembelajaran yang ditetapkan pun tidak tercapai. Maka dari itu, siswa perlu berusaha untuk menciptakan sendiri suasana belajar yang baik dan memberikan feedback positif agar pembelajaran yang diterapkan oleh guru dapat berjalan dengan efektif.

Sriyono (Sriyono, 2016) mengemukakan pendapatnya bahwa dengan adanya kemandirian belajar akan membuat seorang siswa selalu konsisten dan bersemangat belajar dimanapun dan kapan pun, hal tersebut dikarenakan dalam diri siswa tertanam kesadaran dan kebutuhan belajar melalui tugas dan 
kewajiban. Maka, Siswa perlu mengelola sendiri aktivitas belajarnya agar dapat memenuhi kewajiban belajarnya dan menyelesaikan tugas-tugas yang diberikan oleh guru.

\section{Rancangan Program Bimbingan Belajar untuk Meningkatkan Kemandirian Belajar siswa}

Program yang dirancang dalam penelitian mengenai kemandirian belajar siswa kelas IX di SMPN 3 Kota Serang yaitu program bimbingan belajar. Hal-hal yang dibutuhkan dalam merancang program bimbingan belajar, yaitu data yang akan menjadi acuan dalam merancang program bimbingan belajar. Data yang digunakan yaitu data hasil analisis instrumen mengenai kemandirian belajar siswa kelas IX SMPN 3 Kota Serang.

Berdasarkan hasil pengolahan data kuesioner, diperoleh persentase tertinggi yaitu di kategori rendah sebanyak 159 siswa dengan persentase $100 \%$ pada sub indikator motivasi belajar, 114 siswa dengan persentase $71.70 \%$ pada sub indikator evaluasi, dan 33 siswa dengan persentase $20.76 \%$. Hasil tersebut dijadikan sebagai dasar kebutuhan siswa dalam penyusunan rancangan program bimbingan belajar. Berikut merupakan rincian deskripsi kebutuhan sebagai dasar pembuatan program.

Tabel 5. Deskripsi Kebutuhan

\begin{tabular}{|l|l|l|}
\hline $\begin{array}{l}\text { Sub } \\
\text { Indikator }\end{array}$ & Hasil Asesmen Kebutuhan & Rumusan kebutuhan \\
\hline $\begin{array}{l}\text { Motivasi } \\
\text { belajar }\end{array}$ & $\begin{array}{l}\text { Siswa jarang membaca } \\
\text { buku setiap harinya }\end{array}$ & $\begin{array}{l}\text { Membudayakan } \\
\text { kebiasaan membaca }\end{array}$ \\
\hline $\begin{array}{l}\text { Strategi } \\
\text { belajar }\end{array}$ & $\begin{array}{l}\text { Siswa memilih untuk } \\
\text { mencontek jawaban } \\
\text { teman dari pada } \\
\text { mengerjakannya sendiri }\end{array}$ & $\begin{array}{l}\text { Melatih diri untuk } \\
\text { belajar mandiri }\end{array}$ \\
\hline Evaluasi & $\begin{array}{l}\text { Siswa jarang mempelajari } \\
\text { kembali setiap bab }\end{array}$ & $\begin{array}{l}\text { Membiasakan diri } \\
\text { untuk mengulas materi }\end{array}$ \\
\hline
\end{tabular}




\begin{tabular}{|l|l|l|}
\hline & $\begin{array}{l}\text { pelajaran ketika sudah } \\
\text { selesai dibahas oleh guru }\end{array}$ & kembali \\
\hline
\end{tabular}

Strategi layanan yang dapat diberikan kepada siswa pun beragam. Namun, perlu disesuaikan dengan kebutuhan siswa. Strategi layanan yang dapat diterapkan yaitu bimbingan klasikal, bimbingan lintas kelas, bimbingan kelompok, konseling kelompok, konseling individu, dan sebagainya. Adapun komponen layanan yang digunakan yaitu layanan dasar, layanan responsif, layanan perencanaan individual, dan dukungan system.

Sugandi (2013) menjelaskan bahwa layanan dasar diartikan sebagai proses pemberian bantuan kepada seluruh konseli melalui kegiatan penyiapan pengalaman terstruktur secara klasikal atau kelompok yang dirancang dan dilaksanakan secara sistematis dalam rangka mengembangkan kemampuan penyesuaian diri yang efektif sesuai dengan tahap dan tugas perkembangannya. Yusuf dan Juntika (2010: 31) menjelaskan bahwa layanan responsif adalah layanan bantuan bagi para siswa yang memiliki kebutuhan atau masalah yang memerlukan bantuan (pertolongan) dengan segera. Layanan perencanaan individual merupakan layanan bantuan kepada semua siswa agar mampu membuat dan melaksanakan perencanaan masa depannya, berdasarkan pemahaman akan kekuatan dan kelemahan dirinya. Dukungan sistem merupakan komponen layanan dan kegiatan manajemen yang tidak secara langsung memberikan bantuan kepada siswa, atau memfasilitasi kelancaran perkembangan siswa.

\section{Simpulan}

Profil mengenai kemandirian belajar siswa kelas IX di SMPN 3 Kota Serang Tahun Ajaran 2019/2020 diperoleh hasil kemandirian belajar siswa berada pada kategori sedang dengan persentase sebesar 67.78\%, yang artinya bahwa sebagian besar siswa cukup memiliki kemandirian belajar. Siswa yang kemandirian belajarnya dalam kategori sedang dapat dikatakan sudah cukup memiliki 
kemandirian belajar, namun belum sepenuhnya dapat melaksanakan aktivitas yang menunjukan kemandirian belajar secara rutin.

Aspek kemandirian belajar pada indikator personal attributes memperoleh hasil persentase sebesar $74.85 \%$ yang termasuk dalam kategori sedang. Pada aspek personal attributes sebagian besar siswa dapat dikatakan cukup mampu memilih sumber belajar yang sesuai, menentukan strategi belajar yang tepat, dan motivasi belajar yang perlu ditingkatkan kembali. Indikator processes memperoleh hasil persentase sebesar $71.07 \%$ yang termasuk dalam kategori sedang. Pada aspek processes sebagian besar siswa dapat dikatakan cukup mampu untuk membuat perencanaan belajar, melakukan monitoring, dan evaluasi belajar. indikator learning context memperoleh hasil persentase sebesar $67.92 \%$ yang termasuk dalam kategori sedang. Pada aspek learning context sebagian besar siswa dapat dikatakan cukup mampu untuk bisa mengatur kegiatan belajar di sekolah maupun di rumah.

Kemandirian belajar dapat di tingkatkan melalui program bimbingan belajar. Rancangan program bimbingan belajar untuk kemandirian belajar siswa dapat dijadikan pedoman dalam memberikan layanan kepada siswa. Pemberian layanan dapat dilakukan menggunakan strategi bimbingan klasikal, bimbingan kelompok, konseling kelompok, konseling individu serta penggunaan media bimbingan dan konseling. Rancangan program bimbingan belajar diharapkan dapat membantu siswa untuk meningkatkan kemandirian belajarnya. 


\section{DAFTAR PUSTAKA}

Ahmadi, A., \& Uhbiyati, N. (2012). Ilmu Pendidikan. Jakarta: Bumi Aksara.

Bastomi, H. (2017). Menuju Bimbingan Konseling Islami. KONSELING EDUKASI: Journal of Guidance And Counseling, 1 No. 1. https://doi.org/10.21043/konseling.v1i1.4434

Bunandar, A. S. E. (2016). Analisis Kemandirian Belajar Siswa Pada Mata Pelajaran Biologi Dikelas X Mas Al-Mustaqim Kubu Raya. Universitas Muhammadiyah Pontianak.

Darmawanti, A. (2017). Pengaruh Motivasi Belajar terhadap Kemandirian Belajar pada Siswa yang di Mediasi oleh Kreativitas (Universitas Muhammadiyah Malang). Universitas Muhammadiyah Malang. Retrieved from https://www.eprints.umm.ac.id

Haefany, R. M. (2015). Layanan Bimbingan Belajar Sebagai Upaya Meningkatkan Kemandirian Belajar Siswa Tunagrahita Di SLB Negeri 2 Yogyakarta. Universitas Islam Negeri Sunan Kalijaga Yogyakarta.

Hidayati, R. (2013). Model Bimbingan Kelompok dengan Taknik Stimulus Control untuk Meningkatkan Kemandirian Belajar Siswa. Jurnal Bimbingan Konseling, 2 NO 2. https://doi.org/10.15294/JUBK.V2I2.2721

Indaryanti, T. (2019). Pengembangan Panduan Cognitive Behavior Counseling Untuk Meningkatkan Kemandirian Belajar Pada Siswa Kelas IX di SMP Negeri 3 Berbah (Universitas Ahmad Dahlan Yogyakarta). Universitas Ahmad Dahlan Yogyakarta. Retrieved from http://eprints.uad.ac.id/14997/

Isnawati, N., \& Samian. (2015). Kemandirian Belajar Ditinjau Dari Kreativitas Belajar dan Motivasi Belajar Mahasiswa. Jurnal Pendidikan Ilmu Sosial, 25 (1).

Kurniawati, D. (2010). Upaya Meningkatkan Kemandirian Belajar Siswa Dalam Pembelajaran Matematika Melalui Model Cooperative Learning Tipe Kepala Bernomor Tersturktur Pada Siswa SMPN 2 Sewon Bantul. Universitas Negeri Yogyakarta.

Mohammad, A., \& Asrori, M. (2011). Psikologi Remaja Perkembangan Peserta Didik. Jakarta: Bumi Aksara.

Munadiroh, L. (2015). Perbedaan Kemandirian dalam Belajar di Tinjau dari Persepsi Terhadap Pola Asuh Orang Tua Pada Siswa SMP Negeri 4 Bangkalan. UIN Sunan Ampel Surabaya.

Mustika, Z. (2015). Pentingnya Peranan Walikelas Dalam Pembelajaran. Jurnal Intelektualita, 3 No.1.

Nurihsan, J., \& Yusuf, S. (2010). Landasan Bimbingan dan Konseling. Bandung: 
Remaja Rosdakarya.

Rimawati, E. (2016). Pengaruh Lingkungan Sekolah dan Pemanfaatan Sumber Belajar terhadap Prestasi Belajar Siswa pada Mata Pelajaran EKonomi Kelas XI IPS di SMA Negeri 1 Muaro Jambi. Universitas Jambi.

Saidah, S. (2014). Hubungan Antara Kepercayaan Diri Dengan Kemandirian Siswa Akselerasi MAN I Model Bojonegoro. Universitas Islam Negeri Maulana Malik Ibrahim Malang.

Santosa, B. A. (2014). Perbedaan Kemandirian Belajar Matematika Pada Siswa Program Akselerasi dan Reguler SMPN 1 Boyolali Tahun Ajaran 2012/2013. Universitas Kristen Satya Wacana Yogyakarta.

Song, L., \& Hill, J. R. (2007). A Conceptual Model for Understanding Self-Directed Learning in Online Environments. Journal of Interactive Online Learning, 1, No.6, 27-42.

Sriyono, H. (2016). Program Bimbingan Belajar Untuk Membantu Meningkatkan Kemandirian Belajar Siswa. Jurnal Sosio-E-Kons, 8, No.2.

Suardana. (2012). Implementasi Model Belajar Mandiri Untuk Meningkatkan Aktivitas, Hasil, dan Kemandirian Belajar Mahasiswa. Jurnal Pendidikan Dan Pengajaran, 45, No.1, 56-65.

Sugandi, A. I. (2013). Pengaruh Pembelajaran Berbasis Masalah dengan Setting Kooperatif Jigsaw terhadap Kemandirian Belajar Siswa SMA. Infinity Journal, 2, No.2. https://doi.org/10.22460/infinity.v2i2.p144-155

Surur, N. (2004). Pengembangan Program Bimbingan dan Konseling yang Berorientasi Kecakapan Hidup. Bandung: PPS UPI.

Syahputra, D. (2017). Pengaruh Kemandirian Belajar dan Bimbingan Belajar Terhadap Kemampuan Memahami Jurnal Penyesuaian Pada Siswa SMA Melati Perbanungan. AT-TAWASSUTH: Jurnal Ekonomi Islam, 2, No.2, 368-388.

Thoken, F., Asrori, \& Purwanti. (2017). Analisis Kemandirian Belajar Pada Siswa Kelas X SMA Kemala Bhayangkari Sungai Raya. Jurnal Pendidikan Dan Pembelajaran Khatulistiwa, Vol 6, No.

Unsuri, Y. (2009). Pengaruh Penerapan Metode Belajar Resource Based Learning Terhadap Peningkatan Kemandirian Belajar Siswa Pada Bidang Studi PAI Kelas IX di SMP Negeri 2 Kalitidu Bojonegoro. IAIN Sunan Ampel Surabaya.

Yanti, S., \& Surya, E. (2017). Kemandirian Belajar dalam Memaksimalkan Kualitas Pembelajaran. Researchgate. Retrieved from https://www.researchgate.net/publication/321833928_KEMANDIRIAN_BEL AJAR_DALAM_MEMAKSIMALKAN_KUALITAS_PEMBELAJARAN 